\title{
Evaluation of the Mutagenic Effects of SV40 in Mouse, Hamster, and Mouse-Human Hybrid Cells
}

\author{
Richard E. Giles, ${ }^{1,2}$ Frederick M. Boyce, ${ }^{1,3}$ and William W. Brockman ${ }^{1}$ \\ ${ }^{1}$ Department of Microbiology, The University of Michigan Medical School, Ann Arbor, Michigan 48109 \\ Received 9 January 1991-Final 18 April 1991.
}

\begin{abstract}
We have examined the ability of SV40 to induce changes in drug or temperature resistance in mouse, hamster, and mouse-human hybrid cells. SV40 induced a substantial increase of cells resistant to 5-bromodeoxyuridine + trifluorothymidine in Balb/c $3 T 3$ cells and induced an increase of hybrid cells resistant to 6-thioguanine. SV40 was found to be nonmutagenic or weakly mutagenic in other test systems. The $3 T 3$ cells were T-antigen positive, exhibited a marked reduction in TK activity, were heterogeneous for $\left[{ }^{3} \mathrm{H}\right] \mathrm{BrdU}$ incorporation by autoradiography, and exhibited instability of the drug-resistance phenotype, suggesting that SV4O may be inducing resistance by an epigenetic process. SV40-induced 6-thioguanine resistance in the hybrids appears to occur predominantly by chromosome loss.
\end{abstract}

\section{INTRODUCTION}

SV40 interacts with cells that are not permissive for viral replication in several ways. In many infected cells, abortive transformation occurs: the viral $T$ antigens are expressed; synthesis of cellular DNA is stimulated; and a limited number of cell divisions are induced. In a fraction of infected nonpermissive cells, SV40 DNA is inserted into the cellular DNA. If the portion of the integrated viral DNA encoding large $T$ antigen is expressed, the cell becomes stably transformed and continues to exhibit altered growth properties. If the integrated viral DNA is not expressed as functional large $T$ antigen, the cell remains cryptically trans- formed (1). The integration of viral DNA in both overt and cryptic transformants might be expected on occasion to disrupt cellular genes, either during initial insertion into the host genome or during subsequent rearrangements occurring in SV40-transformed cells $(2,3)$.

SV40 has been reported to induce chromosome and karyotype abnormalities (4-8). Some of these chromosome aberrations may result in inactivation of host genes or other alterations in host gene expression. Specific chromosome aberrations in human cells transfected with origin defective SV40 have been associated with immortilization (9) and tumorigenicity (10).

Mutations at several different selectable

\footnotetext{
${ }^{1}$ Department of Microbiology, The University of Michigan Medical School, Ann Arbor, Michigan 48109 ${ }^{2}$ Present address: Department of Veterinary Microbiology and Pathology, Washington State University, Pullman, Washington 99164-7040.

${ }^{3}$ Present address: Department of Genetics, Enders 560, Children's Hospital, 300 Longwood Ave., Boston, Massachusetts 02115 .
} 
loci have been reported to be induced shortly after SV40 infection of mouse, hamster, and human cells $(7,11-13)$. These mutagenic effects are variable. Investigators have reported no mutagenic effect of SV40 in some experiments and 12-fold or greater increases in the frequency of mutants in other experiments. Conflicting results have been obtained regarding the role of $T$ antigen in SV40-mediated mutagenesis $(13,15-16)$. The underlying mechanism(s) of these mutagenic effects of $S V 40$ is not known.

Vogt and Dulbecco (17) proposed the hypothesis that mutagenic effects of papovaviruses may play a role in transformation and tumorigenesis. Our studies were initiated to gain a better understanding of the nature of SV40-induced mutagenesis and the role SV40 mutagenesis might play in T-antigenindependent SV40-mediated cell transformation.

We examined the ability of SV40 to induce mutants resistant to six different selection conditions in a variety of mammalian cells. We found that, in most instances, infection by SV40 does not increase the frequency of mutants above the spontaneous frequency seen in uninfected cells. We have, however, detected two noteworthy instances of SV40-induced drug resistance: one appears to represent an epigenetic phenomenon and the other to be the result of whole chromosome loss. In the first case, infection with SV40 produced a striking induction of $\mathrm{Balb} / \mathrm{c} 3 \mathrm{~T} 3$ cells resistant to the pyrimidine analogs 5-bromodeoxyuridine (BrdU) and trifluorothymidine (TFT). The second instance of SV 40 mutagenesis was noted when interspecific hybrid cells infected with SV40 were observed to lose two distinct human $\mathrm{X}$ chromosome loci coordinately. Instability of the BrdU/TFT-resistant mutants suggests that on occasion SV40 may induce epigenetic events that confer drug resistance. The coordinate loss of two selectable markers on the same human chromosome from the hybrid cells indicates that SV40 may induce whole chromosome loss.

\section{MATERIALS AND METHODS}

Cells. The origins of the untransformed heteroploid Balb/c 3T3 cells (Bc3T3) and BSC-1 cells have been described elsewhere $(18,19)$. CHEF/18 cells are normal diploid Chinese hamster cells (20). $\mathrm{LMTK}^{-} \mathrm{APRT}^{-}$ cells are chemically transformed heteroploid mouse strain L cells (21-23) resistant to $\mathrm{BrdU}(24,25)$ and diaminopurine (26). tsC $1 \mathrm{AG}^{\mathrm{R}}$ is a heat-sensitive, azaguanineresistant mutant derived from mouse $L$ cells (27). The 462-10 near-diploid spontaneously transformed Chinese hamster cells (28) are resistant to BrdU and deficient in thymidine kinase $\left(\mathrm{TK}^{-}\right.$). CHO-K1 (CCL61) neardiploid spontaneously transformed Chinese hamster cells were obtained from the American Type Culture Collection (12301 Parklawn Dr., Rockville, Maryland 20852). The origin and characteristics of $157 \mathrm{BnpT}-1$, a heteroploid mouse-human hybrid cell line (tsC1AG ${ }^{\mathrm{R}}$ X GM126), have been described (29). $157 \mathrm{BnpT}-1 \mathrm{~B}$ is a subclone of $157 \mathrm{BnpT}-1$, and BSC-1E is a subclone of BSC-1. Cells were grown in $5 \mathrm{ml} / 25 \mathrm{~cm}^{2} \alpha$-MEM supplemented with $10 \%$ fetal or calf bovine serum and were equilibrated with $5 \% \mathrm{CO}_{2}$ in air.

Vinus. SV40 strain $776(18,19)$ was propagated on BSC-1 or BSC-1E cells at a multiplicity of infection of $10^{-2}-10^{-3}$ plaqueforming units (PFU) per cell to obtain a crude cell lysate that was concentrated by either: polyethylene glycol precipitation (30); pH 5.6 precipitation (Course Manual: Animal Virus Course, Cold Spring Harbor Laboratory, Cold Spring Harbor, New York 11724, H. Diggelmann and P. Beard, pp. 5-6, 1976); or a modification of the $\mathrm{pH} 5.6$ procedure. The modified $\mathrm{pH} 5.6$ procedure was as follows: (1) When approximately $90 \%$ of the cells exhibited typical SV40 CPE, the cultures were frozen and thawed three times 
and the debris collected by scraping with a rubber policeman into medium containing $2 \%$ fetal bovine serum (FBS). (2) The medium was acidified by adding $1 / 50$ to $1 / 100$ vol of $2 \mathrm{M} \mathrm{KNa}_{2} \mathrm{PO}_{4}$ pH 5.6. (3) The acidified crude lysate was incubated overnight at $4^{\circ} \mathrm{C}$. (4) Virus was pelleted by centrifugation at $8000 \mathrm{~g}$ for $40 \mathrm{~min}$ at $4^{\circ} \mathrm{C}$ and resuspended in $1 / 40$ volume of medium with $2 \%$ FBS. (5) The concentration of $\mathrm{NaHCO}_{3}$ was adjusted to $50 \mathrm{mM}$ with $7.5 \% \mathrm{NaHCO}_{3}$ and the virus suspension was stirred overnight at $4^{\circ} \mathrm{C}$. (6) The resuspended virus concentrate was sonicated at full power using a Heat Systems model W375 with a $431 \mathrm{~A}$ cup horn for $3 \mathrm{~min}$ at room temperature. (7) The sonicated virus concentrate was centrifuged at $8000 \mathrm{~g}$ for 10 min at $37^{\circ} \mathrm{C}$. The supernatant was collected and saved and the pellet resuspended in medium with $2 \% \mathrm{FBS}$ and $50 \mathrm{mM} \mathrm{NaHCO}$ (half the volume of the step 6 virus concentrate), sonicated, and centrifuged as described. The second supernatant was added to the first step 7 supernatant. Virus concentrates produced by this procedure yielded titers ranging from 1.7 to $9.5 \times 10^{10} \mathrm{PFU} / \mathrm{ml}$. Mock-infected BSC-1 cells were frozen and thawed three times in medium with $2 \%$ fetal bovine serum to produce a mock lysate. A mock lysate processed by the modified $\mathrm{pH}$ 5.6 procedure gave rise to the mock lysate concentrate.

Infection Protocol. Medium was removed from monolayers, and virus was added at a multiplicity of infection ranging from $10^{2}$ to $8 \times 10^{4}$ in a volume of $0.2-3.0$ $\mathrm{ml} / 25 \mathrm{~cm}^{2}$ for $2-5 \mathrm{~h}$. After infection, growth medium was added without removing unab. sorbed virus.

Drug Selection Systems. Drug selection systems used were: 6-thioguanine (6TG, 25 $\mu \mathrm{g} / \mathrm{ml}$ ) for loss of hypoxanthine-guanine phosphoribosyltransferase (HPRT); BrdU $(30 \mu \mathrm{g} / \mathrm{ml})$ and TFT $(1 \mu \mathrm{g} / \mathrm{ml})$ were used in combination for stringent selection for loss of $\mathrm{TK}$; and cytosine arabinoside ( $\operatorname{araC}, 1 \mu \mathrm{g} / \mathrm{ml}$ ) for loss of deoxycytidine kinase (dCK). HAT medium (hypoxanthine, $10^{-4} \mathrm{M}$; aminopterin, $4 \times 10^{-7} \mathrm{M}$; and thymidine, $1.6 \times 10^{-5}$ M) was used to select for $\mathrm{TK}^{+}$cells. Colonies were stained with Wright's stain.

Temperature Selection. tsClAG ${ }^{\mathrm{R}}$ cells and 157BnpT-1 mouse-human hybrids that lack the heat-resistance locus $h r C l(C 1 H R, H u-$ man Gene Mapping Conference, 31) located on the human $\mathrm{X}$ chromosome are killed at the nonpermissive temperature (npT) of $38.5^{\circ} \mathrm{C}$, but grow at the permissive temperature (pT) of $34^{\circ} \mathrm{C}$ (29). 157BnpT-1 and derivatives that have the human $X$ chromosome grow at both the permissive temperature and nonpermissive temperature, as do heat-resistant revertants of $\operatorname{tsClAG}^{\mathrm{R}}$. Hybrids that grow in $\mathrm{TG}$ at the nonpermissive temperature represent presumptive $X$ chromosome rearrangement events or mutation at the HPRT locus. Hybrids that grow in 6TG at the permissive temperature and are heat sensitive without selection for loss of the $\mathrm{hrCl}$ locus represent presumptive human $X$ chromosome loss events.

Chromosome Loss Test. To test for whole chromosome loss, mouse-human hybrid cells grown under selective conditions to fix the human $X$ chromosome markers are shifted to nonselective conditions and exposed to the test agent for a specific time (time of treatment). The time of treatment was typically five days for virus, colchicine, or colcemid. After treatment, the cells are grown under nonselective conditions in the absence of the test agent for a specific time (time of expression) to permit the phenotypic expression of any mutations induced during the treatment period. After the expression period, the cells are selected in 6TG at the permissive temperature or nonpermissive temperature for a period of approximately 10 days to two weeks and the frequency of colony-forming cells ( $\mathrm{CFC}$ ) is determined at the permissive temperature and nonpermissive temperature. Treatment controls consist 
of cells treated with medium, with a drug known to induce chromosome loss such as colchicine or colcemid (32-34), or with a mock lysate. Strong presumptive evidence for whole human $\mathrm{X}$ chromosome loss is that the frequency of CFC in $6 \mathrm{TG}$ permissivetemperature test cultures is greater than the frequency of $\mathrm{CFC}$ in $6 \mathrm{TG}$ permissivetemperature control cultures and that the frequency of 6TG-resistant cells that are heat sensitive in the test cultures is greater than the frequency of $6 \mathrm{TG}$ resistant cells that are heat sensitive in the control cultures. Strong evidence for human $\mathrm{X}$ chromosome rearrangement or mutagenesis at the structural gene locus of human HPRT is that the frequency of $\mathrm{CFC}$ in $6 \mathrm{TG}$ nonpermissivetemperature test cultures is greater than the frequency of CFC in 6TG nonpermissivetemperature control cultures.

T-Antigen Staining. T-antigen-positive cells grown on glass slides were visualized by indirect immunofluorescence assay (IFA) using anti-SV40 hamster antiserum (Office of Program Resources and Logistics, National Cancer Institute) and fluorescein isothiocyanate-conjugated goat or rabbit antihamster serum after fixation in acetone at $-20^{\circ} \mathrm{C}$.

TK Assay. Cells from three $15-\mathrm{cm}$ tissue culture dishes were harvested, resuspended in $0.5 \mathrm{ml}$ of extraction buffer $(10 \mathrm{mM} \mathrm{KCl}, 1$ $\mathrm{mM} \mathrm{MgCl}, 50 \mu \mathrm{M}$ thymidine, $3 \mathrm{mM} \beta$-mercaptoethanol, and $10 \mathrm{mM}$ Tris $\mathrm{HCl}, \mathrm{pH} 8.0$ ), frozen and thawed four times, and centrifuged in a Beckman microfuge at approximately $10,000 \mathrm{~g}$ for $20 \mathrm{~min}$ at $4^{\circ} \mathrm{C}$. The supernatant was collected and stored at $-70^{\circ} \mathrm{C}$ prior to assay as described (35). Protein was assayed by the method of Lowry et al. (36). TK activity was expressed as the counts per minute per microgram protein per $30 \mathrm{~min}$ relative to $\mathrm{Bc} 3 \mathrm{~T} 3(100 \%)$.

$\left.l^{3} H\right] B r d U$ Uptake. Cells were seeded into 24-well plates at $10^{4}$ cells/well in growth medium and incubated for $24-48 \mathrm{~h}$ at $37^{\circ} \mathrm{C}$. The cells, at approximately $50 \%$ confluency, were labeled with $\left[{ }^{3} \mathrm{H}\right] \mathrm{BrdU} 1 \mu \mathrm{Ci} / \mathrm{ml}$ in
$\alpha$-MEM with $1 \%$ fetal calf serum at $37^{\circ} \mathrm{C}$. Duplicate wells were rinsed three times with phosphate-buffered saline, and the cells were lysed by the addition of $0.25 \mathrm{ml}$ of $10 \mathrm{mM}$ EDTA plus $0.6 \%$ SDS (sodium dodecylsulfate). The lysate was removed and acid precipitable radioactivity was determined by spotting $0.2 \mathrm{ml}$ of lysate onto a Whatman GF/B filter previously soaked in 5\% TCA. The filter was rinsed extensively with $5 \%$ TCA, 95\% ethanol, dried, and counted in nonaqueous scintillation fluid. Incorporation of $\left[{ }^{3} \mathrm{H}\right] \mathrm{BrdU}$ by $\mathrm{Bc} 3 \mathrm{~T} 3$ was linear over at least a 4 -h time period. $\left[{ }^{3} \mathrm{H}\right] \mathrm{BrdU}$ uptake was expressed as the counts per minute per milligram protein per hour relative to $\mathrm{Bc3T} 3$ $(100 \%)$ at the 1 -h time point.

Autoradiography. Cells were grown in 1.6- $\mathrm{cm}^{2}$ wells as described above and labeled for $10-24 \mathrm{~h}$ with $1 \mu \mathrm{Ci} / \mathrm{ml}$ of $\left[{ }^{3} \mathrm{H}\right] \mathrm{BrdU}$. The medium was removed and the cells washed twice with PBS. The cells were fixed with $100 \%$ ethanol-glacial acetic acid $(3: 1, \mathrm{v} / \mathrm{v})$ for $5 \mathrm{~min}$ followed by $5 \%$ TCA for $5 \mathrm{~min}$. The cells were washed three times in $70 \%$ ethanol and once with $100 \%$ ethanol for 10 min each. Each well was coated with Kodak NTB2 emulsion and exposed in a lightproof box kept at $4^{\circ} \mathrm{C}$ for five days. The emulsion was developed with Kodak D-19 developer, fixed, and the cells were examined using phasecontrast microscopy.

\section{RESULTS}

Expression of T Antigen. Effects of SV40 were assessed in transformed and untransformed cells that are either diploid, near diploid, or heteroploid (Table 1). T-antigen staining was done to determine the infectability of target cells, which should directly affect the frequency of cells subject to SV40 mutagenic effects. This assay depends on the ability of infected cells to express the early genes of SV40 as well as to take up and uncoat SV40 virions. The presence of detectable $\mathrm{T}$ antigen varied considerably among the various cell lines (Table 1). Spontane- 
Table 1. Characteristics of Cell Lines and T-Antigen Expression

\begin{tabular}{|c|c|c|c|}
\hline Cell line & Chromosome number & Growth phenotype & $\begin{array}{l}\text { T-antigen } \\
\text { expression }\end{array}$ \\
\hline $\begin{array}{l}\text { CHOK1 } \\
\text { Chinese hamster }\end{array}$ & Near diploid & Transformed (spontaneously) & $\operatorname{Low}(0.4 \%)$ \\
\hline $\begin{array}{l}462-10 \\
\text { V79 Derivative Chinese } \\
\text { hamster }\end{array}$ & Near diploid & Transformed (spontaneously) & Undetectable \\
\hline $\begin{array}{l}\mathrm{LMTK}^{-} \\
\text {L derivative mouse }\end{array}$ & Heteroploid & Transformed (chemically) & $\operatorname{Low}(2.9-3.5 \%)$ \\
\hline $\begin{array}{l}\text { tsCl } \\
\quad \mathrm{L} \text { derivative mouse }\end{array}$ & Heteroploid & Transformed (chemically) & Low $(0.5-1.4 \%)$ \\
\hline $\begin{array}{l}\text { CHEF } \\
\text { Chinese hamster }\end{array}$ & Diploid & $\begin{array}{l}\text { Untransformed permanent } \\
\text { cell line }\end{array}$ & Moderate $(8.2 \%)$ \\
\hline $\begin{array}{l}\mathrm{Bc} 3 \mathrm{~T} 3 \\
\text { Balb c derivative mouse }\end{array}$ & Heteroploid & $\begin{array}{l}\text { Untransformed permanent } \\
\text { cell line }\end{array}$ & High $(68 \%)$ \\
\hline $\begin{array}{l}\text { 157BnpT-1B } \\
\text { Mouse-human hybrid tsCl } \\
\text { mouse cells } \times \text { untrans } \\
\text { formed human cells }\end{array}$ & $\begin{array}{l}\text { Heteroploid, approx. } \\
80 \text { mouse and } 3 \\
\text { human chromo- } \\
\text { somes }\end{array}$ & Transformed (chemically) & High $(78 \%)$ \\
\hline
\end{tabular}

${ }^{a}$ The frequency of T-antigen-positive cells was determined by IFA five to six days after infection at an MOI of $10^{4}$.

ously transformed Chinese hamster cell lines and chemically transformed mouse $L$ cell lines expressed little or no $T$ antigen. The low level of $T$ antigen expression in mouse $\mathrm{L}$ cells may be due to reduced uptake of SV40, since

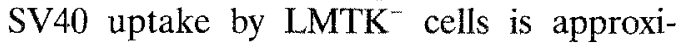
mately 500 -fold less efficient than uptake by primary monkey cells and approximately 120 -fold less efficient than uptake by CV-1 cells (37). Untransformed Chinese hamster cells exhibited a moderate frequency of T-antigen-positive cells, while the untransformed mouse $\mathrm{Bc} 3 \mathrm{~T} 3$ cells had a high frequency of $\mathrm{T}$-antigen-positive cells. The mouse-human hybrid cell line exhibited a very high frequency of T-antigen-positive cells. The hybrid contained human chromosomes $3,14, \mathrm{X}$, and possibly chromosome 15 in addition to approximately twice the number of mouse chromosomes found in tsC1 cells. It is possible that the human chromosomes present in the hybrid enable these cells to either take up, uncoat, or express SV40 more efficiently than the parental mouse cells.

Effect of SV4O on Drug or Temperature Resistance in CHOK1, 462-10, LMTK , tsC1, and CHEF Cells. We did not observe SV40 induction of $\mathrm{CHOK} 1$ mutants resistant to araC (Table 2). A small increase in the frequency of 6TG-resistant cells was noted in CHOK1 cells, but the significance of this increase is questionable due to the fact that the fractional error was high in both the control and the infected cultures. The 462-10 Chinese hamster cells exhibited a modest increase in the frequency of araC-resistant cells after infection with SV40 (Table 2). When SV40-infected 462-10 cells were treated with a low concentration of colcemid to promote chromosome loss and uncover recessive mutations, the frequency of araCresistant cells was increased several-fold relative to the medium and mock lysate controls and the culture treated with SV40 alone. These results suggest that SV40 may induce recessive mutations or cryptic mutagenic events that may be uncovered by chromosome loss. When SV40-infected 462-10 cells were selected for resistance to $6 \mathrm{TG}$, a small increase was noted when the infected cells were treated with colcemid. The high background frequency of $6 \mathrm{TG}$ resistant cells in $462-10$ limits the sensitivity of this test system.

We examined LMTK for forward muta- 


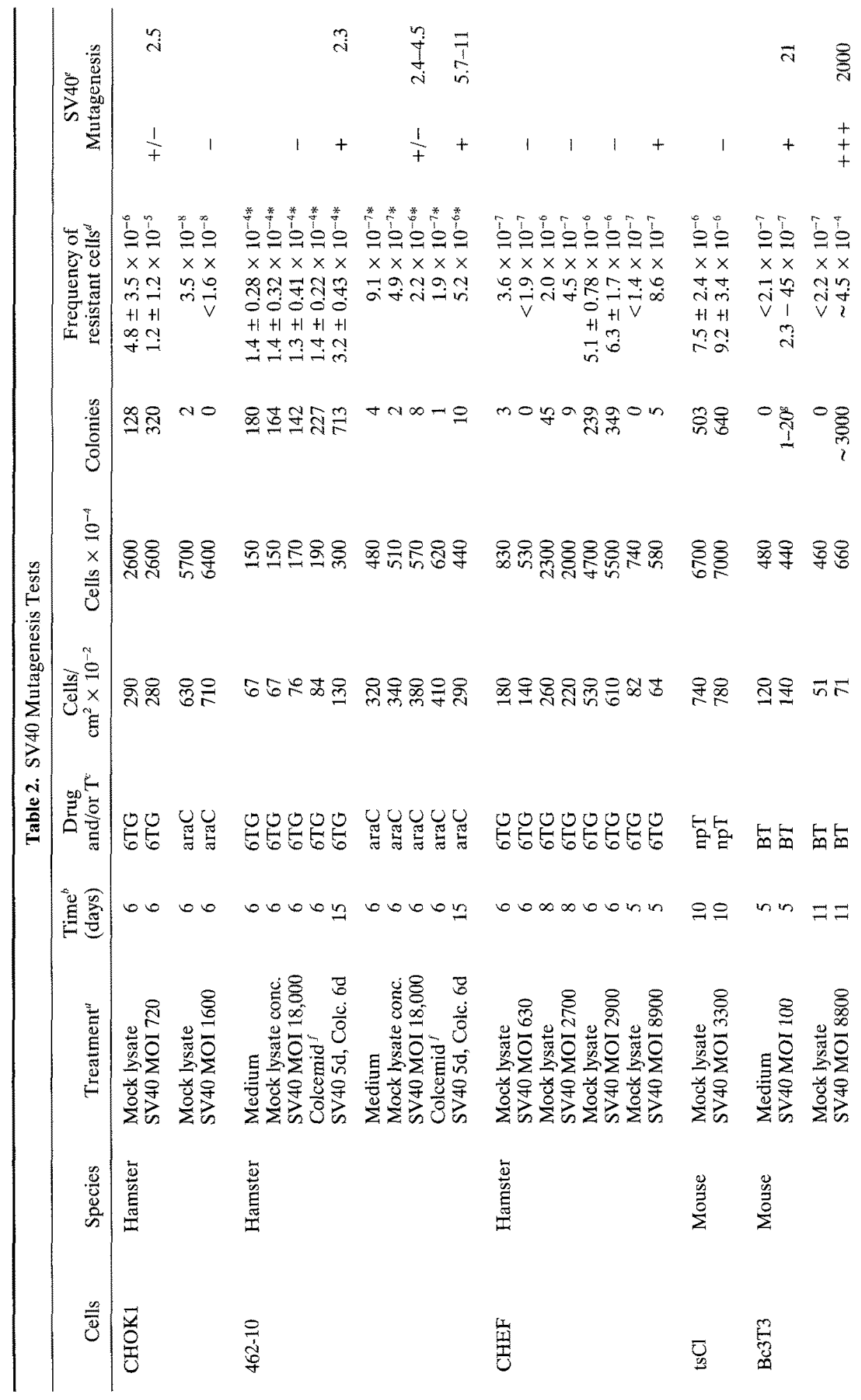




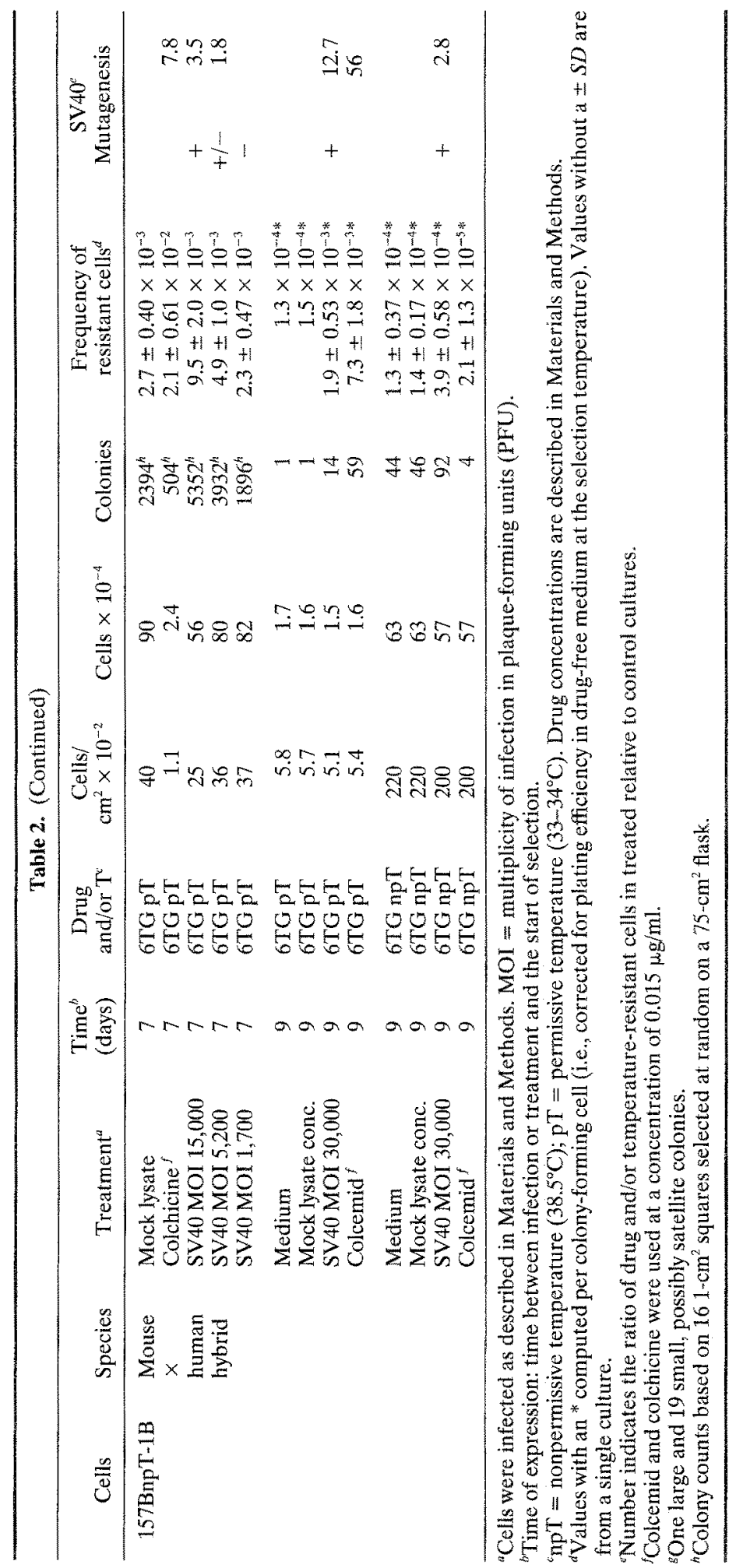


tion to $6 \mathrm{TG}$ resistance after infection and failed to detect any 6TG-resistant mutants, although a reconstruction experiment using a defined mixture of 6TG-resistant tsCl cells and 6TG-sensitive LMTK $^{-}$cells demonstrated that 6TG resistant mutants should have been recoverable under the conditions of this experiment (data not shown). We tested heat-sensitive $\mathrm{tsCl}$ mouse cells for the presence of mutants resistant to heat after infection. SV40 did not enhance the frequency of heat-resistant revertants (Table 2).

CHEF cells express a moderate level of SV40 $\mathrm{T}$ antigen in contrast to CHOK1, 462-10, LMTK- ${ }^{-}$, and tsCl, which express only low levels of $\mathrm{T}$ antigen. Three experiments with CHEF cells (Table 2) produced no evidence for $\mathrm{SV} 40$-induced resistance to 6TG. One infection of CHEF cells at a high multiplicity of infection yielded five 6TGresistant clones, none of which expressed SV40 $T$ antigen detectable by IFA or immunoprecipitation PAGE analysis.

Induction of Resistance to Thymidine Analogs in SV40-Infected Bc3T3 Cells. The $\mathrm{Bc} 3 \mathrm{~T} 3$ line of mouse cells is readily infected by SV40. Transformation of Bc3T3 cells has been studied extensively $(2,19)$ and occurs at a frequency of $10^{-5}$ transformants/PFU. Integration of SV40 DNA in Bc3T3 cells occurs at a high frequency (1). After infection with SV40, the majority of Bc3T3 cells also express $\mathrm{T}$ antigen (Table 1). One of three plates of SV40 infected Bc3T3 cells selected for resistance to $\mathrm{BrdU}+\mathrm{TFT}$ (presumptive $\mathrm{TK}^{-}$) yielded one very large colony and several small colonies that may have been satellite colonies. A number of these BrdU + TFT (BT) -resistant colonies were picked and maintained as independent cell clones (9C series). All nine clones tested were positive for $\mathrm{T}$-antigen expression. When $9 \mathrm{C}$ clones were plated in HAT medium, which selects for $\mathrm{TK}^{+}$cells, HAT-resistant cultures readily became established in a single passage. Subclones isolated from 9C primary clones in BT medium exhibited a high frequency of HAT-resistant cells $\left(10^{-3}\right.$ $10^{-4}$ ), which suggests that the drug-resistance phenotype is unstable. Infection of Bc3T3 cells at a higher multiplicity of infection $\left(8.8 \times 10^{3}\right)$ led to an increase in the frequency of cells resistant to BT (68B series cell lines). The $68 \mathrm{~B}$ series cell lines also exhibited a high background frequency of HAT-resistant cells.

BrdU Uptake and TK Activity. To ascertain the nature of the thymidine analog resistance in the SV40-infected Bc3T3 cells, we analyzed $\left[{ }^{3} \mathrm{H}\right] \mathrm{BrdU}$ uptake and TK activity in BT-resistant cell lines, Bc3T3 cells, and SV40-transformed Bc3T3 cells not selected for drug resistance. $\left[{ }^{3} \mathrm{H}\right] \mathrm{BrdU}$ uptake was linear with time and varied in different BT-resistance cell lines from $1.2 \%$ to $8.7 \%$ of the uptake exhibited by untransformed Bc3T3 cells (Table 3). Two SV40-transformed lines, not selected for drug resistance, had levels of $\left[{ }^{3} \mathrm{H}\right] \mathrm{BrdU}$ uptake of $80 \%$ and $130 \%$ relative to Bc3T3 cells (Table 3), which demonstrated that the reduction of BrdU uptake in the BT-resistant cells was not a simple consequence of SV40 infection, T-antigen expression, or SV40-mediated transformation. The uptake of $\left[{ }^{3} \mathrm{H}\right]$ thymidine was measured and was found to be proportional

Table 3. BrdU Incorporation and TK Activity in 9C and $68 \mathrm{~B}$ Clones Resistant to BrdU and TFT

\begin{tabular}{|c|c|c|c|}
\hline \multirow[b]{2}{*}{ Cells } & \multicolumn{2}{|c|}{ BrdU incorporation } & \multirow{2}{*}{ 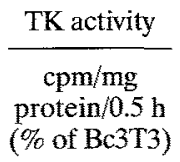 } \\
\hline & $\begin{array}{c}\mathrm{cpm} / \mathrm{mg} \\
\text { protein } / h^{\alpha} \\
(\% \text { of } \mathrm{Bc} 3 \mathrm{~T} 3)\end{array}$ & $\begin{array}{l}\text { Percent }^{b} \\
\text { labeled } \\
\text { nuclei }\end{array}$ & \\
\hline $9 C-4-1$ & 8.7 & 15 & 6.7 \\
\hline $9 C-5-3$ & 5.9 & 24 & 1.7 \\
\hline 68B1 & 1.2 & 2.2 & 0.72 \\
\hline $68 \mathrm{B3}$ & 2.0 & 0.6 & 1.9 \\
\hline $\mathrm{Bc3T} 3$ & 100.0 & 81 & 100.0 \\
\hline LMTK & 0.2 & $\mathrm{ND}$ & 1.0 \\
\hline $\mathrm{A} 7 \mathrm{~B} 4 \mathrm{~b}^{\mathrm{E}}$ & 80 & ND & 76 \\
\hline WTBla $^{c}$ & 130 & $\mathrm{ND}$ & ND \\
\hline \multicolumn{4}{|c|}{$\begin{array}{l}\text { One-hour labeling period at } 37^{\circ} \mathrm{C} \text {. } \\
\text { Determined by autoradiography. } \\
\text { SV } 40 \text {-transformed } \mathrm{Bc} 3 \mathrm{~T} 3 \text { cells not selected for drug } \\
\text { resistance. }\end{array}$} \\
\hline
\end{tabular}


to the uptake of $\left[{ }^{3} \mathrm{H}\right] \mathrm{BrdU}$ for all cell lines tested (data not shown).

TK activity in BT-resistant cells, Bc3T3 cells, and SV40-transformed Bc3T3 cells not selected for drug resistance paralleled the BrdU uptake results. TK activity in BTresistant cells ranged from $0.72 \%$ to $6.7 \%$ of the activity exhibited by untransformed $\mathrm{Bc} 3 \mathrm{~T} 3$ cells. An SV40-transformed cell line not selected for drug resistance possessed $76 \%$ of wild-type Bc3T3 TK activity, while LMTKcells, a thoroughly studied stable mutant cell line deficient in TK, expressed only $1 \%$ of the Bc3T3 level of TK. Mammalian cells take up thymidine via two systems: a low-affinity nonconcentrative facilitated diffusion process that is a general pathway for nucleoside uptake $(38,39)$ and a high-affinity concentrative process dependent on the presence and specific type of TK expressed in the mammalian cell (39). The difference observed in BrdU uptake between BT-resistant cells and $\mathrm{Bc} 3 \mathrm{~T} 3$ at low substrate concentration probably reflects a difference in the TK-dependent high-affinity system, which suggests that the key defect in BT-resistant cells is a loss of TK activity that both prevents BrdU and TFT incorporation and reduces BrdU (and probably TFT) uptake.

Autoradiography was performed on cell monolayers of BT-resistant cells and $\mathrm{Bc} 3 \mathrm{~T} 3$ cells exposed to medium containing $\left[{ }^{3} \mathrm{H}\right] \mathrm{BrdU}$. The nuclei in the $\mathrm{Bc3T} 3$ monolayers were uniformly heavily labeled, while the majority of cell nuclei in the BT-resistant cell monolayers were unlabeled. However, the BT-resistant cell lines exhibited a background of heavily labeled cell nuclei. The 9C-4-1 and 9C-5-3 subclones had $15 \%$ and $24 \%$ heavily labeled nuclei, while 68B1 and $68 \mathrm{~B} 3$ had $2.2 \%$ and $0.6 \%$ heavily labeled nuclei, respectively. The results of the autoradiography experiments are consistent with the TK activity and BrdU uptake observam tions and indicate that the small amount of residual TK activity and BrdU uptake is due to a small fraction of cells with near-normal phenotype rather than a uniform low level of TK activity in all cells. Since the drugresistance phenotype is relatively unstable and cloned cell populations (9C series) are heterogeneous in phenotype, the drugresistant cells may not be mutants at the level of DNA sequence but may be due to an epigenetic phenotype switching event induced by SV 40 infection.

Effect of SV40 Infection on Thioguanine Resistance in Mouse-Human Hybrid Cells. To test for SV40-induced chromosome loss or chromosome rearrangement, we examined the frequency of thioguanine-resistant cells in SV40-infected 157BnpT-1B cells that express high levels of SV40 T antigen after infection. These hybrid cells have two selectable markers on the human $\mathrm{X}$ chromosome: HPRT, which confers sensitivity to $6 \mathrm{TG}$ and resistance to HAT medium, and CIHR, a locus which confers resistance to $38.5^{\circ} \mathrm{C}$, which is the nonpermissive temperature of the heat-sensitive mutant mouse cell used to construct the hybrid. These two selectable markers on the same chromosome permit a direct test for whole chromosome loss induced by any potentially clastogenic agent, since loss of the whole human $\mathrm{X}$ chromosome results in a cell that is simultaneously 6TG resistant, HAT sensitive, and temperature sensitive.

SV40-infected hybrid cells that survive 6TG selection may have undergone any of a number of mutagenic events capable of conferring resistance to $6 \mathrm{TG}$, such as whole $\mathrm{X}$ chromosome loss, breakage or rearrangement of the $\mathrm{X}$ chromosome followed by loss or inactivation of the HPRT locus located in the distal long arm of the human X chromosome, insertional inactivation of the HPRT locus by SV40, or other mutagenic event (base substitution, deletion, etc.) in the structural or regulatory region of the HPRT locus. It is assumed that the probability of simultaneous structural gene mutations at two loci is low compared to the probability of whole chromosome loss. Interspecific mouse- 
human hybrids generally exhibit preferential loss of human chromosomes at a rate substantially higher than the spontaneous frequency of 6TG-resistant mutants in mammalian cells $(40-42)$.

SV40-infected hybrid cells were tested for the frequency of $6 \mathrm{TG}$-resistant cells at $33^{\circ} \mathrm{C}$ seven days after treatment at $33^{\circ} \mathrm{C}$ with a mock cell lysate, colchicine at $0.015 \mu \mathrm{g} / \mathrm{ml}$ for five days, or SV40 at multiplicities of infection of 1700,5200 , or 15,000 for five days. Cells treated with colchicine, an agent known to induce chromosome loss, exhibited a 7.8-fold increase in the frequency of 6TG-resistant cells relative to the mock lysate control, while cells infected with SV40 at the highest multiplicity of infection showed a 3.5-fold increase (Table 2). The effect of SV40 infection on the frequency of 6TGresistant hybrid cells appeared to be proportional to the multiplicity of infection, since only a marginal increase was noted at an intermediate multiplicity of infection and no effect was observed at the lowest multiplicity of infection.

To determine whether the increase in 6TG-resistant cells represented chromosome loss, an experiment was performed in which the frequency of 6TG-resistant cells was determined at the permissive temperature and at the nonpermissive temperature. In this experiment, colcemid was used instead of colchicine. Colcemid produced a dramatic 56 -fold increase in the frequency of 6TGresistant cells at the permissive temperature. Greater than $99 \%$ of the colcemid-induced 6TG-resistant hybrids were heat sensitive, which demonstrated that the 6TG-resistant cells lacked both the HPRT and C1HR loci and probably arose through colcemidinduced loss of the human $\mathrm{X}$ chromosome. SV40 infection produced a 12.7 -fold increase in the frequency of 6TG-resistant hybrids at the permissive temperature and a 2.8 -fold increase in the frequency of 6TG-resistant hybrids at the nonpermissive temperature.
These observations indicated that most of the 6TG-resistant mutants induced by SV40 probably represented human $\mathrm{X}$ chromosome loss events because $80 \%$ of the 6 TG-resistant hybrids have also lost the X-linked heatresistance locus C1HR. Twenty percent of the SV40-treated 6TG-resistant hybrids have the CIHR locus and represent X chromosome rearrangement events or mutagenesis at the HPRT locus.

\section{DISCUSSION}

We found SV40 to be nonmutagenic or weakly mutagenic in cell lines expressing $T$ antigen at levels ranging from undetectable to moderate. The lack of ability to detect mutagenic effects may be due to: the ability of the host cell to absorb, internalize, and uncoat virions; host cell effects on virus gene expression; host cell response to viral gene products; the linkage arrangement of nonessential selectable genes with respect to essential genes; metabolic cooperation and cell density at selection; and gene copy number of loci subjected to selection (43, 44). The modest mutagenic effects of SV40 noted by others are probably not significantly different from the small increases we observed in the frequency of 6TG-resistant cells in SV40-infected cultures of CHOK1, 46210 , or CHEF.

The cell lines in our study that had the highest infection rates, $\mathrm{Bc} 3 \mathrm{~T} 3$ and the mouse-human hybrid, exhibited the most significant levels of induced drug-resistant cells (viz. $10^{-3}-10^{-4}$ ). The SV40-induced changes in $T K$ gene expression in Bc3T3 cells indicate that this virus can alter the host cell phenotype by epigentic processes that result in destabilization of gene expression. The observation that SV40 induces whole chromosome loss demonstrates a clastogenic effect of this virus capable of inducing aneuploidy in infected cells. Epigenetic processes leading to unstable phenotype switching and 
aneuploidy may contribute to cell transformation and variations in the transformed cell phenotype.

Phenotype Switching. The TK ${ }^{-}$Bc3T3 cell lines resulting from SV40 infection appear to be mixtures of cells lacking TK activity and cells that contain normal or near-normal levels of TK. Since subcloning fails to eliminate the background of $\mathrm{TK}^{+}$cells from $\mathrm{TK}^{-} \mathrm{BT}$-resistant cells, these $\mathrm{TK}^{+}$cells must arise through some type of phenotypic switching event. Phenotypic switching at a high frequency at the $T K$ locus has been observed in both mouse and human cells. Bastow et. al., (45) and Ostrander et. al., (46) reported that LMTK $^{-}$cells containing an active herpes simplex (HSV) TK gene yielded $\mathrm{TK}^{-}$clones at a high frequency. Ostrander et. al., (46) observed 5-azacytidine-inducible phenotypic switching from HSV TK ${ }^{-}$to HSV $\mathrm{TK}^{+}$, which appeared to be associated with gene methylation. Harris (47) and Wise and Harris (44) have shown that expression of the cellular $T K$ gene in Chinese hamster V79 cells may be controlled by methylation and that methylation of the cellular $T K$ gene may be involved in the isolation of TK $\mathrm{TK}^{-}$mutants. The molecular nature of the phenotype switching event in $9 \mathrm{C}$ and $68 \mathrm{~B}$ cell lines derived from Bc3T3 is unknown but may involve an epigenetic process such as gene methylation rather than a genetic change in nucleotide sequence. Such an epigenetic effect might be transdominant and lead to the appearance of $\mathrm{TK}^{-}$cells at a high frequency despite the fact that the $T K$ gene is an autosomal gene and would be expected to be present in Bc3T3 hypotetraploid cells at two to four copies per cell.

Epigenetic Effects of $S V 40$. Epigenetic effects of SV40 on host cell gene expression have been described by Soprano et al. (48), who noted an SV40 T antigen-dependent activation of human rDNA genes in mousehuman hybrid cells. Parker et al. (49) found that the alpha $2(1)$ procollagen gene was transcriptionally inactivated in SV40-transformed WI38 cells but was active in normal WI38. Matsumura et al. $(50,51)$ reported that human diploid fibroblasts exhibit declining levels of methylation during passage but that methylation levels are maintained in SV40-transformed precrisis human diploid fibroblasts. During the course of studies investigating the possible role of methylation in inactivation of tumor suppressor genes, de Bustros et al. (52) discovered that SV40infected human cells exhibit altered methylation in the region of the calcitonin gene. Epigenetic effects of SV40 on the host cell genome may play a role in mediating SV40-induced cell transformation.

Clastogenic Effects of SV4O. We exploited the properties of a hybrid cell line that contains a human $\mathrm{X}$ chromosome carrying two selectable markers on a mouse L-cell background. The human $\mathrm{X}$ chromosome is dispensable when the hybrid cells are grown under nonselective conditions, which permits these cells to be used to test for clastogenic agents using $\mathrm{X}$-linked selective markers. In contrast, whole $\mathrm{X}$ chromosome loss in CHOK1, 462-10, and CHEF is likely to be lethal, and these cell lines are not suitable for testing virus-induced whole chromosome loss using selectable X-linked markers.

When the hybrids were treated with low concentrations of a drug known to produce whole chromosome loss or nondisjunction, a substantial increase in the frequency of 6TG-resistant heat-sensitive cells was observed, which is indicative of whole chromosome loss. After SV40 infection, the hybrid cells also exhibited an increase in human $X$ chromosome loss, albeit not as great as the loss produced by colcemid treatment. This clastogenic effect of SV40 could mimic various classical chemical mutagens such as ethyl methane sulfonate by uncovering preexisting recessive mutations in heteroploid cultured cells. Ornitz et al. (53) described two stages in the development of SV40- 
induced pancreatic adenocarcinoma in transgenic mice: an initial preneoplastic stage, in which $\mathrm{T}$ antigen is expressed and morphological progression occurs from hyperplasia to dysplasia, and a second stage characterized by tumor nodules with aneuploid DNA contents. These investigators suggest that the transformation events that they observed may occur coincidently with chromosome loss.

\section{SUMMARY}

Our results demonstrate that SV40 may induce whole chromosome loss in addition to the well-known ability of SV40 to induce chromosome rearrangements and structural abnormalities. Our observation of SV40. induced unstable TK ${ }^{-}$mutants in Bc3T3 cells demonstrates a new epigenetic effect of SV40 infection on the cell phenotype. The extent of SV40 epigenetic effects on host cell transformation remains to be elucidated. In view of the ubiquitious presence of papovaviruses related to $\mathrm{SV} 40$ in the human population $(54,55)$ it may be of interest to determine if other papovaviruses are capable of inducing similar effects.

\section{ACKNOWLEDGMENTS}

We thank Ms. Joan B. Christensen for excellent assistance in the performance of T-antigen analysis by PAGE. This work was supported by Public Health Service grant CA19816 to W.W.B., grant 1F32-GM07163 to R.E.G., by Advanced Genetics Research Institute (AGRI), Oakland, California, and by Washington State University grant $11 \mathrm{H}$ 2540-9072 to R.E.G. from National Institutes of Health BRSG funds and American Cancer Society funds. In memory of W.W.B., deceased 1984.

\section{LITERATURE CITED}

1. Brockman, W.W., Christensen, J.B., Ryan, K.W., Souwaidane, M., and Imperiale, M.J. (1987). Virology 158:118-125.
2. Bender, M.A., and Brockman, W.W. (1981). I. Virol. 38:872-879.

3. Sager, R., Anisowicz, A., and Howell, N. (1981). Cell 23:41-50.

4. Wolman, S.R., Hirschhorn, K., and Todaro, G.J (1964). Cytogenetics 3:45-61.36.

5. May, E., May, P., and Weil, R. (1971). Proc. Natl. Acad. Sci. U.S.A. 68:1208-1211.

6. Harnden, D.G. (1974). In Chromosomes and Cancer, German, J. (ed.) (John Wiley, New York), pp. $150-190$.

7. Marshak, M.I., Varshaver, N.B., and Shapiro, N.I. (1975). Mutat, Res. 30:383-396.

8. Ray, F.A., Peabody, D.S., Cooper, J.L., Cram, L.S., and Kraemer, P.M. (1990). $J$. Cell. Biochem. 42:13-31.

9. Naiman, T., and Canaani, D. (1989). Cancer Genet. Cytogenet. 40:65-71.

10. Stacey, M., Gallimore, P.G., McConville, C., and Taylor, A.M.R. (1990). Oncogene 5:727-739.

11. Theile, M., Scherneck, S., and Geissler, E. (1976). Mutat. Res. 37:111-124.

12. Varshaver, N.B., Marshak, M.I., Luss, E.V., Gorbunova, L.V., and Shapiro, N.I. (1977). Mutat. Res. 43:263-278.

13. Theile, M., Strauss, M., Luebbe, L., Scherneck, S., Krause, H., and Geissler, E. (1980). Cold Spring Harbor Symp. Quant. Biol. 44:377-382.

14. Theile, M., Scherneck, S., and Geissler, E. (1980). Arch. Virol 55:293-309.

15. Zannis-Hadjopoulos, M., and Martin, R.G. (1983). Mol. Cell. Biol. 3:421-428.

16. Theile, M., Krause, H., and Geissler, E. (1987). $J$. Gen. Virol. 68:233-237.

17. Vogt, M., and Dulbecco, R. (1963). Proc. Natl. Acad. Sci. U.S.A. 49:171-179.

18. Danna, K., and Nathans, D. (1971). Proc. Natl. Acad. Sci. U.S.A. 68:2913-2917.

19. Brockman, W.W. (1978). J. Virol. 25:860-870.

20. Sager, R., and Kovac, P.E. (1978). Somat. Cell Genet, 4:375-392.

21. Earle, W.R. (1943). J. Natl. Cancer Inst. 4:165-212.

22. Sanford, K.K., Earle, W.R., and Likely, G.D. (1948). J. Natl. Cancer Inst. 9:229-246.

23. Kuchler, R.J., and Merchant, D.J. (1956). Proc. Soc. Exp. Biol. Med. 110:803.

24. Hsu, T.C., and Somers, C.E. (1962). Exp. Cell Res. 26:404-410.

25. Kit, S., Dubbs, D.R., Pickarski, L.J., and Hsu, T.C. (1963). Exp. Cell Res. 31:297-312.

26. Wigler, M., Pellicer, A., Silverstein, S., Axel, R., Urlaub, G., and Chasin, L. (1979). Proc. Natl. Acad. Sci. U.S.A. 76:1373-1376.

27. Thompson, L.H, Mankovitz, R., Baker, R.M., Wright, J.A., Till, J.E., Siminovitch, L., and Whitmore, G.F. (1971). J. Cell Physiol. 78:431-440.

28. Chu, E.H.Y., and Ho, T. (1970). Mamm. Chromosome News. 11:58-59.

29. Giles, R.E., and Ruddle, F.H. (1979). Genetics 93:975-996.

30. Estes, M.K., Huang, E..S., and Pagano, J.S. (1971). J. Virol. 7:635-641. 
31. Miller, O.J., and Siniscalco, M. (1982). Cytogenet. Cell Genet. 32:179-190.

32. Cox, D.M., and Puck, T.T. (1969). Cytogenetics 8:158-169.

33. Sugawara, S., and Mikamo, K. (1980). Jpn. J. Hum. Genet. 25:235-240.

34. Mikamo, K., and Sugaware, S. (1980). Jpn. J. Hum. Genet. 25:241-248.

35. Schlosser, C.A., Steglich, C., DeWet, J.C., and Scheffler, J.E. (1981). Proc. Natl. Acad. Sci. U.S.A. 78:1119-1123.

36. Lowry, O.H., Rosebrough, N.J., Farr, A.L., and Randall, R.J. (1951).J. Biol. Chem. 193:265-275.

37. Swetly, P., Barbanti-Brodano, G., Knowles, B., and Koprowski, H. (1969).J. Virol. 4:348-355.

38. Ungemach, F.R., and Hegner, D. (1978). HoppeSeyler's Z. Physiol. Chem. 359:845-856.

39. Wohlhueter, R.M., Marz, R., Graff, I.C., and Plagemann, G.W. (1976). J. Cell Physiot. 89:605612.

40. Weiss, M.C., and Green, H. (1967). Proc. Natl. Acad. Sci. U.S.A. 58:1104-1111.

41. Nabholz, M., Miggiano, V., and Bodmer, W. (1969). Nature 223:358-363.

42. Ringertz, N.R., and Savage, R.E. (1976), Cell Hybrids. (Academic Press, New York), pp. 174 175.

43. Siminovitch, L. (1976). Cell 7:1-11.
44. Wise, T.L., and Harris, M. (1988). Somat. Cell Mol. Genet. 14:567-581.

45. Bastow, K.F., Darby, G., Wildy, P., and Minson, A.C. (1980).J. Virol. 36:746-755.

46. Ostrander, M., Vogel, S., and Silverstein, S. (1982). Mol. Cell. Biol. 2:708-714.

47. Harris, M. (1982), Cell 29:483-492.

48. Soprano, K., Dev, V.G., Croce, C.M., and Baserga, R. (1979). Proc. Natl. Acad. Sci. U.S.A. 76:38853889.

49. Parker, M.I., Smith, A.A., and Gevers, W. (1989). J. Biol. Chem. 264:7147-7152.

50. Matsumura, T., Hunter, J.L., Farooq, M., and Holliday, R. (1989). Exp. Cell Res. 184:148-157.

51. Matsumura, T., Malik, F., and Holliday, R. (1989). Exp. Gerontol. 24:477-481.

52. de Bustros, A., Nelkin, B.D., Silverman, A., Ehrlich, G., Poiesz, B., and Baylin, S.B. (1988), Proc. Natl. Acad. Sci. U.S.A. 85:5693-5697.

53. Ornitz, D.M., Hammer, R.E., Messing, A., Palmiter, R.D., and Brinster, R.L. (1987). Science 238:188-193.

54. Yoshiike, K., and Takemoto, K.K. (1986). In The Papovaviridae, Vol. 1. The Polyomaviruses, (ed.) Salzman, N.P. (Plenum Press, New York), pp. 295-326.

55. Walker, D.L., and Frisque, R.J. (1986). In The Papovaviridae, Vol. 1. The Polyomavinuses, (ed.) Salzman, N.P. (Plenum Press, New York), pp. 295-326. 